\title{
STRATEGI PENGEMBANGAN USAHA RUMAH TANGGA
}

\section{Development Strategy Of Household Business}

\author{
Andi Fadhilah, Rahim Darma*, A. Amrullah \\ Program Studi Agribisnis, Departemen Sosial Ekonomi Pertanian, \\ Fakultas Pertanian, Universitas Hasanuddin, Makassar \\ *Kontak penulis: Andi_fadhilah95@yahoo.com
}

\begin{abstract}
This research has been done in Household Business " $X$ ", which is located in Sidrap Regency, South Sulawesi. This research aims to: 1). Analyze the problems that happened in agrosystems case; 2). Analyze various solutions for problems in business development; 3). Formulate actions in achieving the objectives; 4). Implement selected actions. The whole data and information obtained in this research using the APPAS (Analysis of Agrosystem Design and Development) method and AHP (Analysis of Hierarchy Process). APPAS method is one of the learning methods that lead to overcome the problem in relation of the agrosystem case that used as the object of research and also directs to analyze the problem solving and AHP (Analysis Hierarchy Process) that is used to evaluate the alternative actions that must be done for the sake of development of agrosystem case. The result of the analysis shows that Household Business of " $X$ " has the main problem that is Limited Marketing Area. The main problem happened due to the lack of promotion media, the manpower in the marketing department is unavailable, inadequate transportation, and limited equipment units. This main problem is the cause of low incomes, low demand, and low sales. To solve this problem, we have to set the main target that is increasing the revenue. The main target will be achieved if the media promotion increases, availability of manpower, transportation, and equipment units. Achieving the main targets will have an impact on increased of corporate revenue, the demand and the sales.
\end{abstract}

Keywords: Strategiy, Household Business, AHP (Analysis of Hierarchy Process)

\begin{abstract}
Abstrak
Penelitian dilakukan di Usaha Rumah Tangga " $X$ ", yang beralamat di Kabupaten Sidrap, Sulawesi Selatan. Penilitian ini bertujuan untuk: 1). Menganalisis permasalahan yang dimiliki oleh agrosistem kasus; 2). Menganalisis berbagai solusi dari permasalahan dalam rangka pengembangan usaha; 3). Merumuskan tindakantindakan dalam pencapaian sasaran; 4). Mengimplementasikan tindakan-tindakan terpilih. Kesuluruhan data dan informasi yang diperoleh dalam penelitianan ini menggunakan metode APPAS (Analisis Perancangan dan Pengembangan Agrosistem) dan AHP (Analisis Hirarki Proses). Metode berpikir APPAS merupakan salah satu metode pembelajaran yang mengarahkan untuk mengatasi sisi-sisi permasalahan dalam terkait dengan agrosistem kasus yang dijadikan sebagai objek penelitian dan juga mengarahkan untuk menganalisis pemecahan masalah serta AHP (Analisis Hirarki Proses) yang digunakan untuk mengevaluasi alternatif tindakan yang harus dilakukan demi pengembangan agrosistem kasus. Hasil analisis menunjukan bahwa Usaha Rumah Tangga " $X$ " memiliki masalah utama yaitu Daerah Pemasaran Terbatas. Masalah utama ini disebabkan media promosi kurang,
\end{abstract}


tenaga kerja pada bagian pemasaran tidak ada, transportasi kurang memadai, dan unit peralatan terbatas. Masalah utama ini mengakibatkan pendapatan rendah, permintaan rendah, dan penjualan rendah. Untuk menyelesaikan permasalahan ini maka di perlukan sasaran utama yaitu pendapatan meningkat. Sasaran utama akan tercapai apabila media promosi bertambah, tenaga kerja memadai, transportasi yang memadai, dan unit peralatan yang memadai. Pencapaian sasaran utama akan berdampak pada pendapatan perusahaan meningkat, permintaan meningkat dan penjualan meningkat.

Kata Kunci: Strategi, usaha, rumahtangga.

Sitasi: Andi Fadhilah, Rahim Darma*, A. Amrullah, 2018. Strategi Pengembangan Usaha Rumah Tangga, JSEP 14 (3) 233 - 248.

\section{Pendahuluan}

Salah satu bentuk industri kecil yang berkembang di Indonesia adalah di bidang pangan. Menurut Wirakartakusumah (1997), keberadaan industri pangan di Indonesia dapat menyerap tenaga kerja dalam jumlah yang cukup banyak serta mampu mendorong berdirinya industri penunjang seperti industri pengolahan makanan dan industri kemasan.

Kabupaten Sidenreng Rappang selama ini dikenal sebagai penghasil beras terbesar di Sulawesi Selatan. Kabupaten Sidrap terdiri dari 11 kecamatan dan 106 desa/kelurahan. Kabupaten Sidrap adalah salah satu daerah di Sulawesi Selatan yang memiliki potensi pertanian yang sangat luas dengan sistem pengairan yang teratur, pola tanam, dan tata cara penggarapan yang cukup modern yang masa panennya 2 kali setahun. Hingga saat ini, pertanian masih menjadi sektor andalan dalam menopang perekonomian daerah di Kabupaten Sidrap. Sektor ini memberikan kontribusi terbesar dalam pembentukan Produk Domestik Regional Bruto (PDRB) (46\%) dan menyerap kurang lebih 55\% tenaga kerja yang ada. Luas sawah di Kabupaten Sidrap adalah 44,959 Ha, produksi padi pada tahun 2012 adalah 457.986 ton kemudian meningkat sekitar $0,80 \%$ pada tahun 2013 yakni $461.617,45$ ton.

Beras merupakan salah satu tanaman pangan utama dari hampir setengah populasi dunia. Beras dijadikan sumber karbohidrat utama hampir di seluruh daerah di Indonesia karena mudah didapat, rasanya yang enak dan dapat dikombinasikan dengan bahan pangan lain. Sebagai bahan pokok, beras menyumbangkan sekitar 40$80 \%$ energi dan $45-55 \%$ protein dalam rata-rata menu rakyat Indonesia. Didalam bidang ekonomi, beras merupakan sumber pendapatan sebagian besar masyarakat Indonesia, sebagai indeks kestabilan ekonomi, dan landasan utama kebijakan pangan pemerintah.

Tujuan utama dari pengembangan usaha rumah tangga adalah untuk meningkatkan nilai produk yang memanfaatkan sumberdaya alam di Indonesia. Melihat peluang pasar kue tradisional yang cukup cerah dimasa mendatang, maka penulis termotivasi melakukan penelitian dibidang ini agar dapat menelusuri dan mengetahui rantai perjalanan usaha rumah tangga mulai dari pengadaan bahan baku sampai ke tangan konsumen dalam bentuk yang siap dikomsumsi. 
Selain itu dengan hadirnya aneka jenis usaha rumah tangga dibidang pangan akan membuka peluang dalam menjaring tenaga kerja yang berati membantu pemerintah dalam mengurangi pengangguran.

\section{Metode Penelitian}

Strategi pengembangan usaha rumahtangga perlu mendapatkan perhatian dan penelitian yang mendalam khususnya pada masalah dan strategi/tindakan yang diperlukan dalam management produksi dan pemasaran. Penelitian ini mengunakan metode APPAS (Analisis Perancangan dan Pengembangan Agrosistem) akan sangat membantu dimana peran perancangan dan pengembangan agrosistem akan memberikan alternatif pemecahan msalah dalam pengembangan usaha rumahtangga, Analisis ini akan membantu menemukan alternatif tindakan pengelolaan usaha rumah tangga yang mampu mewujudkan efisiensi tenaga, waktu, dan biaya serta meningkatkan pendapatan dan kesejahteraan keluarga.

Penentuan strategi/tindakan terbaik dalam pengelolaan industri rumah tangga dilakukan dengan menggunakan metode Analical Hierarcical Process (AHP). Metode ini dapat mengakomodasi pendekatan kualitatif dan pendekatan kuantitatif dalam menganalisa permasalahan dan alternatif tindakan yang diperlukan untuk mengembangkan usaha rumahtangga. Penggunaan software Expert Choice dalam penelitian ini dimaksudkan untuk memudahkan analisis data dan informasi. Untuk menjaga obyektivitas dan konsistensi penilaian dalam analisa ini, maka digunakan nilai konsistensi. Nilai konsistensi dinyatakan dalam rasio konsistensi (consistency ratio, CR), yang diperoleh melalui penghitungan indeks konsistensi (consistency index, $\mathrm{CI}$ ) dan indeks random konsistensi (consistency random index, RI). Untuk kepentingan evaluasi, CR dengan nilai 0.10 (atau 10\%) atau lebih kecil dianggap dapat diterima (acceptable).

\section{Hasil dan Pembahasan}

Usaha Rumah Tangga " $X$ " adalah sebuah unit usaha kecil menengah yang bergerak dalam bidang pembuatan makanan tradisional di Kabupaten Sidrap Sulawesi Selatan. Pada awalnya pengusaha ini mempunyai inisiatif sendiri untuk menjalankan usaha kecil-kecilan dengan berjualan kue tradisional yang ditawarkan langsung ditempat kerjanya yaitu koperasi yang tidak jauh dari tempat tinggalnya.

Usaha Rumah Tangga ini didirikan sekitar tahun 2008 dengan modal awal sebesar Rp.20.000.000,- dengan peralatan yang cukup memadai. Usaha rumah tangga " $X$ "sampai saat ini hanya dikelola oleh seorang manager dan di bantu oleh 3 orang tenaga kerja. Pemasaran dilakukan langsung ke konsumen dan menitipkan ke tokotoko yang ada dipasarpangkejene. Pada tahun 2010 produk kue tradisional dari usaha rumah tangga " $X$ " memenuhi persyaratan dari dinas kesehatan sesuai dengan nomor pangan industri rumah tangga P-IRT No. 2.06.73.41.01.016 dan nomor izin usaha 560/188-VII/ekon.

Adapun keunggulan produk industri rumahtangga ini adalah bahan baku yang menggunakan produk lokal $100 \%$. Bahan baku lokal yang digunakan adalah tepung beras putih biasa dan gula merah. Jenis beras biasa yang digunakan berupa beras yang ketan dengan proses pembuatan yang unik karena alat yang digunakan sangat 
sederhana. Dintinjau dari aspek kesehatan, kue tradisional ini sangat alami dan menyehatkan mengingat tidak menggunakan bahan pengawet makanan sedikitpun.

\section{a. Analisis Masalah Pengembangan Usaha}

Masalah dan persoalan yang muncul dalam problematisasi ini akan diidentifikasi untuk kemudian disajikan dalam bentuk diagram persoalan. Dengan demikian, dapat diketahui hubungan antara persoalan yangsatu dengan yang lain dalam hubungan sebab akibat dan pada akhirnya dapat diketahui persoalan yang paling mendasar dan spesifik pada agrosistem kasus Analisis ini bertujuan untuk menilai kekurangan, kelemahan dan ketidakpuasan pada komponen-komponen posisi dan kinerja agrosistem dan kemudian dirumuskan sebagai suatu persoalan atau masalah (Djamaluddin, 2010).

Analisis masalah pengembangan agrosistem merupakan suatu kegiatan yang dilakukan untuk mengenali, menguraikan, danmenganalisis permasalahan yang ditemukan pada perusahaan, kemudian dibuat suatu rancangan pemecahan masalah yang dihadapi tersebut. Tujuan utama penyusunan masalah adalahuntuk memudahkan seorang manager untuk mengidentifikasi jenis-jenis persoalan yang dihadapi oleh perusahaan serta mengantisipasi persoalan dengan tindakan pencegahan dan penanggulangan terhadap persoalan masalah tersebut (Mantra, 2011).

\section{b. Identifikasi Masalah}

Identifikasi masalah adalah kegiatan tindak lanjut dari analisis masalah pengembangan usaha setelah ditetapkannya posisi penilaian. Masalah situasi yang memerlukan kita untuk bertindak sepenuhnya atau sebagian saja menjadi tanggung jawab kita.

Problematisasi masalah dimaksudkan sebagai upaya untuk mencari dan menemukan berbagai persoalan yang menghambat kegiatan perusahaan yang dijalankan selama ini. Tujuan pelaksanaan problematisasi adalah untuk memudahkan seorang manajer dalam mengidentifikasi dan mengantisipasinya dengan tindakan pencegahan atau penanggulangan dari persoalan yang dihadapi tersebut (Mantra, 2011).

Terdapat beberapa permasalahan dalam berjalannya seluruh kegiatan pada usaha " $X$ " yang dapat diketahui berdasarkan tabel kesenjangan antara fakta dan harapan Tabel 1: 
Tabel 1

Kesenjangan Fakta dan Harapan pada usaha "X", di Kelurahan Majelling, Kacamatan Maritengngae, Kabupaten Sidrap, 2017.

\begin{tabular}{|c|c|c|c|}
\hline No. & Fakta & Masalah & Harapan \\
\hline \multicolumn{4}{|c|}{ A. Aspek Umum } \\
\hline \multicolumn{4}{|c|}{ Sumberdaya Finansial } \\
\hline 1. & 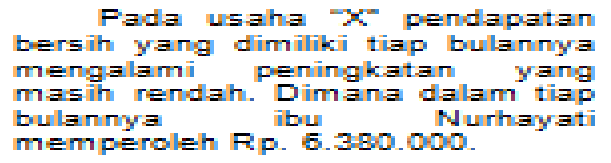 & $\begin{array}{c}\text { Pendapatan } \\
\text { rendah }\end{array}$ & 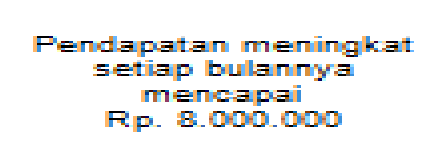 \\
\hline \multicolumn{4}{|c|}{ Sumberdaya Peralatan } \\
\hline 2 & $\begin{array}{l}\text { Tidak adanya kendaraan yang } \\
\text { digunakan untuk memasarkan dan } \\
\text { mengantar sendiri produknga pada } \\
\text { p=langgan dan tempat-tempat } \\
\text { PEmasaran yang baru, sehingga } \\
\text { PEnjuglan produk terbatas. }\end{array}$ & $\begin{array}{c}\text { Transportasi } \\
\text { tidak ada }\end{array}$ & $\begin{array}{l}\text { Adanya satu unit } \\
\text { kendaraan untuk: } \\
\text { memasarkan produk: }\end{array}$ \\
\hline \multicolumn{4}{|c|}{ Sumberdaya Manusia } \\
\hline 3. & $\begin{array}{l}\text { Ten:gga Konja begian pemasaran } \\
\text { belum ada. }\end{array}$ & $\begin{array}{l}\text { Tenaga Kerja } \\
\text { pemacaran } \\
\text { kurang }\end{array}$ & $\begin{array}{c}\text { Tenaga Karja } \\
\text { Eentambah }\end{array}$ \\
\hline \multicolumn{4}{|c|}{ B. Aspek Pennasaran } \\
\hline 4 & 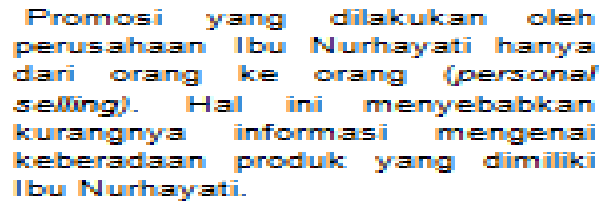 & $\begin{array}{c}\text { Upaya Promosi } \\
\text { Kurang }\end{array}$ & 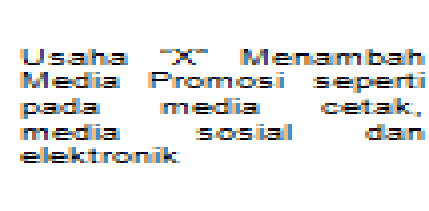 \\
\hline 5. & 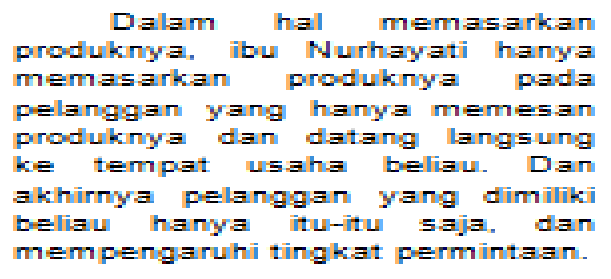 & $\begin{array}{l}\text { Plermintaan } \\
\text { rendah }\end{array}$ & $\begin{array}{c}\text { Dapat meingkatkan } \\
\text { jumlah permintagn dari } \\
20 \text { bugh mencapai } 200 \\
\text { bungkus perhari }\end{array}$ \\
\hline 6. & 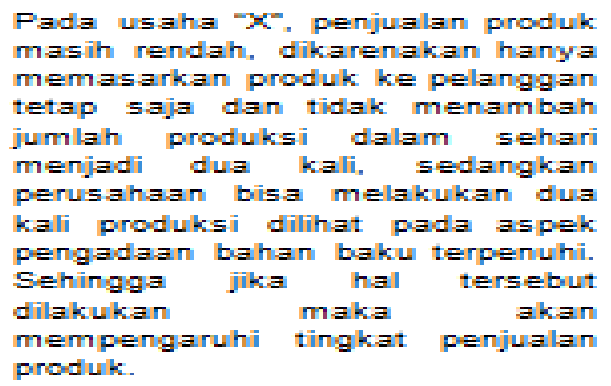 & $\begin{array}{l}\text { Penjualan } \\
\text { rendah }\end{array}$ & 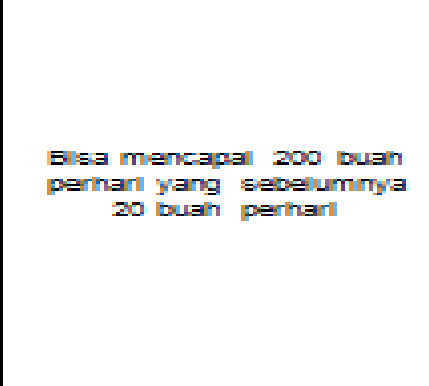 \\
\hline 7 & 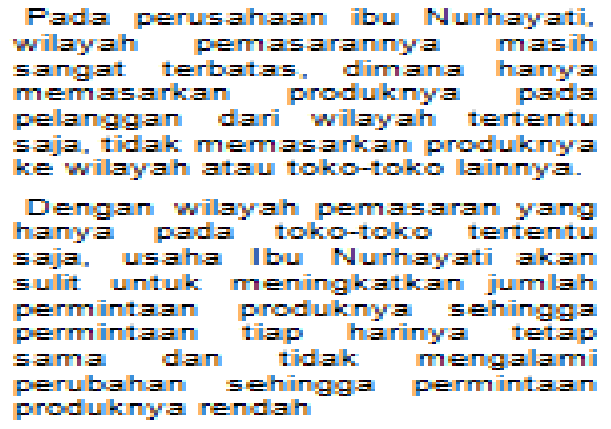 & $\begin{array}{l}\text { Daerah } \\
\text { Pemasaran } \\
\text { terbatas }\end{array}$ & 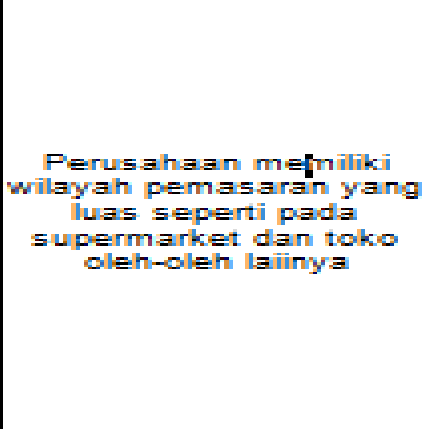 \\
\hline \multicolumn{4}{|c|}{ Aspek Produksi } \\
\hline a. & $\begin{array}{l}\text { Manghasilkan } 20 \text { kemasan dalam } \\
\text { satukali produksi }\end{array}$ & $\begin{array}{l}\text { Skala Produksi } \\
\text { Relatif Rendah }\end{array}$ & $\begin{array}{c}\text { Manghasikan } 200 \\
\text { kemasan diglam seksli } \\
\text { produksi }\end{array}$ \\
\hline
\end{tabular}




\section{Struktur Pohon Masalah}

Identifikasi masalah yang telah dilakukan pada usaha pada dasarnya masalah tersebut memiliki keterkaitan antara masalah yang satu dengan lainnya, dimana ada masalah yang menjadi penyebab masalah lain ataupun suatu masalah yang timbul diakibatkan oleh masalah

yang satu atau sebelumnya. Strukturisasi masalah bertujuan untuk menyusun masalah-masalah yang ditemukan dalam bentuk diagram pohon masalah untuk menghubungkan antara masalah yang satu dengan masalahyang lainnya (Fatma Ariani, 2010).

Pohon masalah adalah suatu teknik untuk mengidentifikasikan semua masalah dalam suatu situasi tertentu dan memperagakan informasi ini sebagai rangkaian hubungan sebab akibat. Pohon masalah dimulai dengan masalah utama. Sebagai hasil analisis situasi di unit kerja, dianalisis penyebab masalah tersebut dalam forum curah pendapat. Mulailah dengan rumusan pernyataan masalah yang dihadapi unit kerja, pikirkan apa akibat yang mungkin timbul dari masalah tersebut secara bertahap, lukislah dalam sebuah bagan pohon (Sartono, 2011).

\section{Gambar 1}

Struktur Pohon Masalah Usaha "X", di Kelurahan Majelling, Kacamatan Maritengngae, Kabupaten Sidrap, 2017.

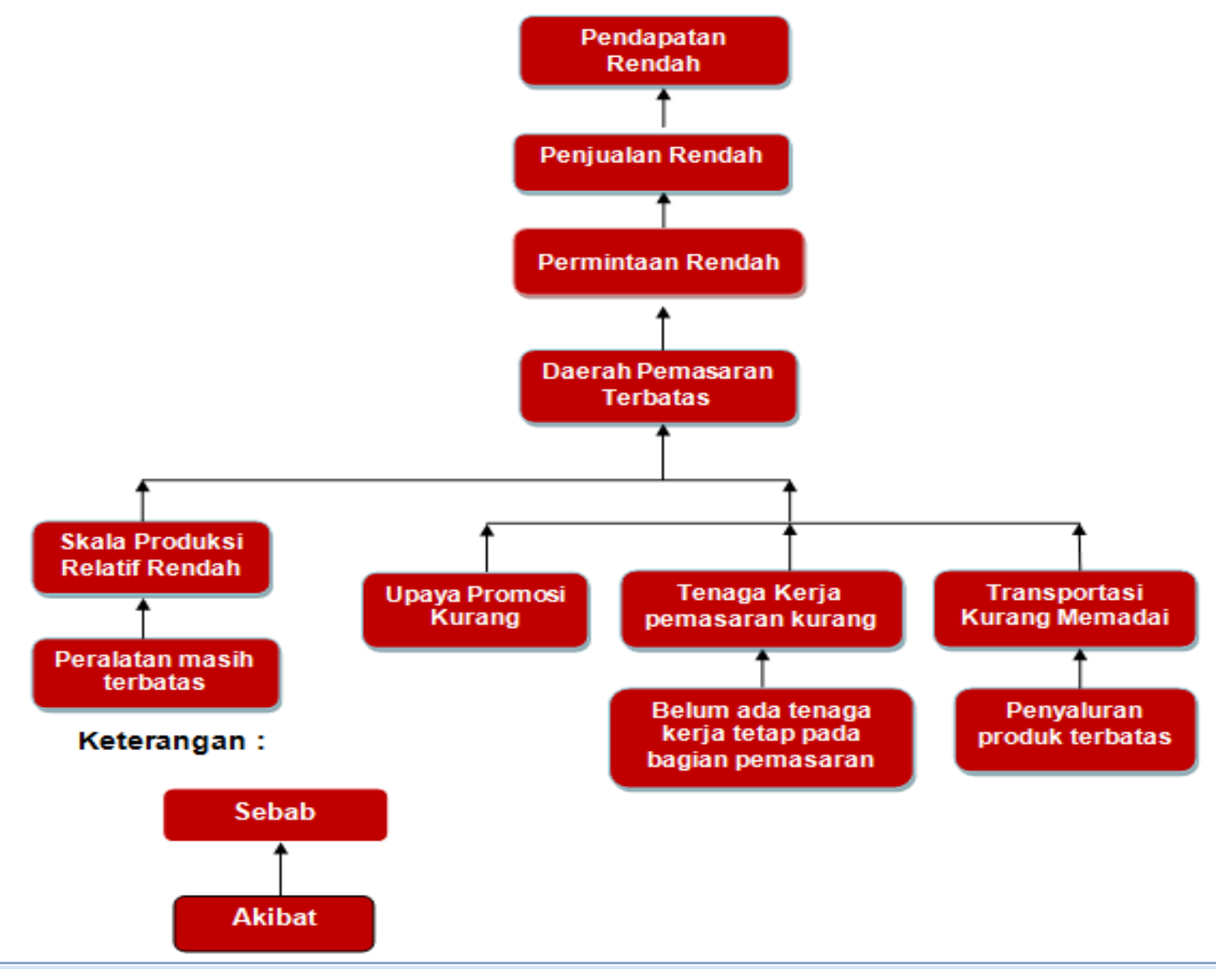

Berdasarkan gambar 1, diketahui bahwa masalah utama pada Usaha " $X$ " adalah "Daerah Pemasaran Terbatas". Masalah utama disebabkan olehmasalah antara yaitu skala produksi rendah, transportasi kurang memadai dan tenaga kerja 
pemasaran kurang serta di sebabkan oleh masalah akar yaitu upaya promosi kurang, unit peralatan masihterbatas,belum adanya tenaga kerja tetap pada bagian pemasaran dan penyaluran produk terbatas.

\section{Penetapan Sasaran}

Setelah mengidentifikasi masalah-masalah yang ditemukan pada tahap analisis masalah, maka untuk mendapatkan perbaikan masalah-masalah tersebut melalui proses transformasi positif, maka selanjutnya kita menentukan sasaransasaran yang hendak dicapai dan menentukan sasaran utama sebagai fokus perhatian untuk diselesaikan dalam rangka perbaikan kinerja perusahaan (AP Hasab, 2010).

Masalah yang telah diidentifikasi pada tahap analisis masalah, selanjutnya diubah pada kondisi positif untuk memperoleh perbaikan dari masalah tersebut.Langkah selanjutnya adalah menentukan sasaran yang hendak dicapai atau penetapan sasaran.Adapun sasaran yang harus dicapai oleh agrosistem kasus adalah sebagai berikut.

1. Pendapatan meningkat

Pendapatan yang diperoleh oleh usaha " $X$ " dapat meningkat sesuai dengan kuantitas yang dimiliki oleh perusahaan, dimana sebelumnyaperusahaan yang mampu melakukan produksi dua kali sehari tapi hanya dilakukan satu kali sehari. Dengan menambah jumlah kegiatan produksi maka akan mempengaruhi jumlah produk yang akan terjual dan akan mempengaruhi pendapatan perusahaan.

2. Penjualan Meningkat

Dengan meningkatnya volume penjualan yang dilakukan oleh perusahan maka akan mempengaruhi tingkat pendapatan yang dimiliki oleh perusahaan.

3. Permintaan Meningkat

Dengan meningkatnya jumlah permintaan, maka produk yang dihasilkan oleh perusahaan akan terjual dengan banyak dan akan mempengaruhi tingkat pendapatan pada perusahaan.

4. Adanya alat transportasi

Dengan adanya alat transportasi khusus untuk perusahaan makan akan semakin memudahkan perusahaan menjalankan usahanya. Dengan memiliki kendaraan akan memudahnya perusahaan untuk memasarkan produknya ke wilayahwilayah lain, memudahkan perusahaan untuk mempromosikan produknya. Dan produk akan dikenal banyak orang dan tetunya akan mempengaruhi permintaan konsumen dan menyebabkan pendapatan meningkat

5. TenagaKerjaPemasaran Bertambah

Dengan bertambahnya tenaga kerja pemasaran maka proses pemasaranakan berjalan dengan lancar dan semakin efisien. Tenaga kerja yang memadai dapat membantu kinerja perusahaan agar bisa berjalan cepat dalam proses pemasaran.

6. Daerah Pemasaran Meluas

Dengan luasnya daerah pemasaran produk maka akan semakin mempengaruhi jumlah produk yang akan terjual dan hal tersebut akan mempengaruhi pendapatan perusahaan.

7. Skala Produksi Meningkat

Suatu perusahaan dapat pemasukan yang besar apabila dapat memproduksi produk yang memiliki khas dan keanekaragaman pada produknya.Begitu juga 
halnya dengan Usaha " $X$ " yang hanya memproduksi kue tradisional dan masih tergolong dalam skala kecil.Pemasukan perusahaan dapat meningkat apabila usaha " $\mathrm{X}$ " memproduksi produk dalam skala yang besar dengan peralatan yang memadai.

8. Media Promosi Bertambah

Kegiatan promosi perlu ditingkatkan agar produk lebih dikenal dimasyarakat luas. Promosi yang baik dapat meningkatkan pendapatan perusahaan. Perusahan dapat menambah kegiatan promosi dalam bentuk media cetak, media sosial maupun elektronik.

\section{Sasaran Utama}

Sasaran utama adalah upaya untuk menyelesaikan masalah utama yang diangkat oleh perusahaan. Diantara semua sasaran yang ada, harus ada sasaran yang ditentukan sebagai sasaran utama. Untuk menentukan sasaran utama, tentunya harus menganalisis semua sasaran terhadap masalah yang terdapat di bagian-bagian yang ada dalam Usaha " $X$ ". Adapun sasaran utama yang didapatkan dan dikemukakan sebelumnya adalah "Daerah Pemasaran Terbatas".

\section{Struktur Pohon Sasaran}

Strukturisasi sasaran merupakan suatu diagram yang hampir sama dengan strukturisasi masalah. Kalau dalam strukturisasi masalah yang dimasukkan dalam Struktur Pohon Masalah adalah masalah yang berindikasi negatif, maka sebaliknya yang dimasukkan dalam struktur(Sumarto, 2009).Pohon Sasaran adalah sasaran (sesuatu yang ingin dicapai) dan berindikasi positif.Gambar berikut ini menyajikan Struktur Pohon Sasaran tersebut.

Gambar 2

Struktur Pohon Sasaran Usaha "X", di Kelurahan Majelling, Kacamatan Maritengngae, Kabupaten Sidrap, 2017.

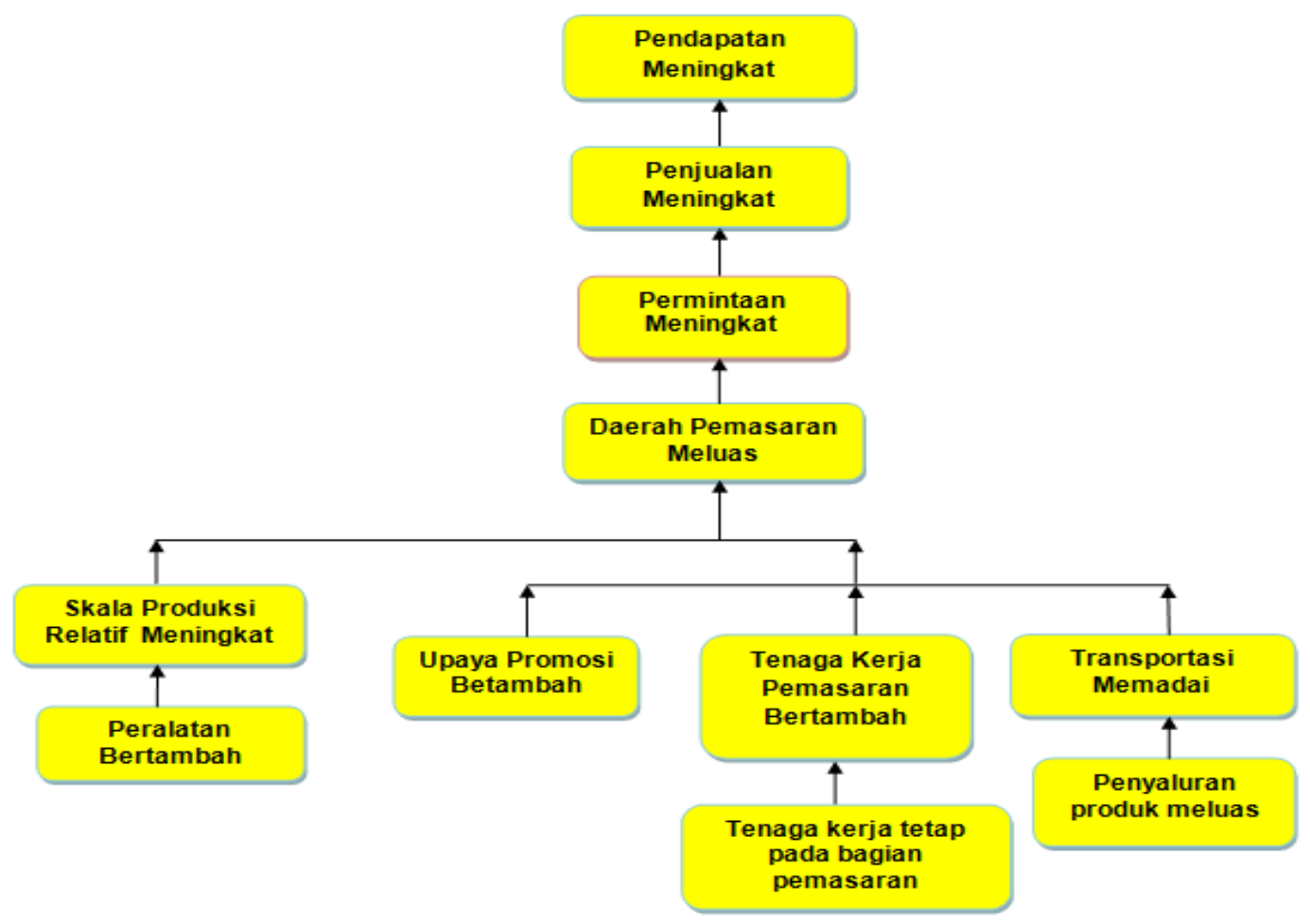


Berdasarkan gambar 2, diketahui bahwa sasaran utama yang ingin dicapai pada usaha " $X$ " adalah "Daerah Pemasaran Meluas".Sasaran utama ini dapat dicapai jika sasaran tercapai yaitu, tenaga kerja pemasaran bertambah, transportasi memadai, upaya promosi bertambah dan unit peralatan bertambah.

\section{Alternatif Tindakan}

Analisis tindakan merupakan hasil yang diperoleh dari evaluasi setiap alternatif yang tersedia terhadap kriteria-kriteria yang telah ditetapkan. Analisis alternatif berguna untuk melihat beberapa kemungkinan pilihan (alternative) hubungan tindakan (rangkaian sasaran) dianalisis

sasaran yang mengarah pada suatu keadaan tertentu. Setelah melalui evaluasi, maka diperlukan suatu alternatif tindakan yang dapat dilakukan untuk mencapai kedua sasaran antara agar sampai pada sasaran utama (Amran, 2011).

Alternatif tindakan dilakukan agar sasaran utama yang telah diitetapkan dapat tercapai/sesuai yang diinginkan.Agar sasaranutama dapat tercapai, maka terlebih dahulu ditetapakan alternatif tindakan pada sasaran antara. Alternatif tindakan yang dapat dilakukan

untuk memenuhi sasaran antara agar sasaran utama dapat tercapai.

\section{Gambar 3}

Struktur Pohon Alternatif Tindakan Usaha "X" di Kelurahan Majelling, Kacamatan Maritengngae, Kabupaten Sidrap, 2017.

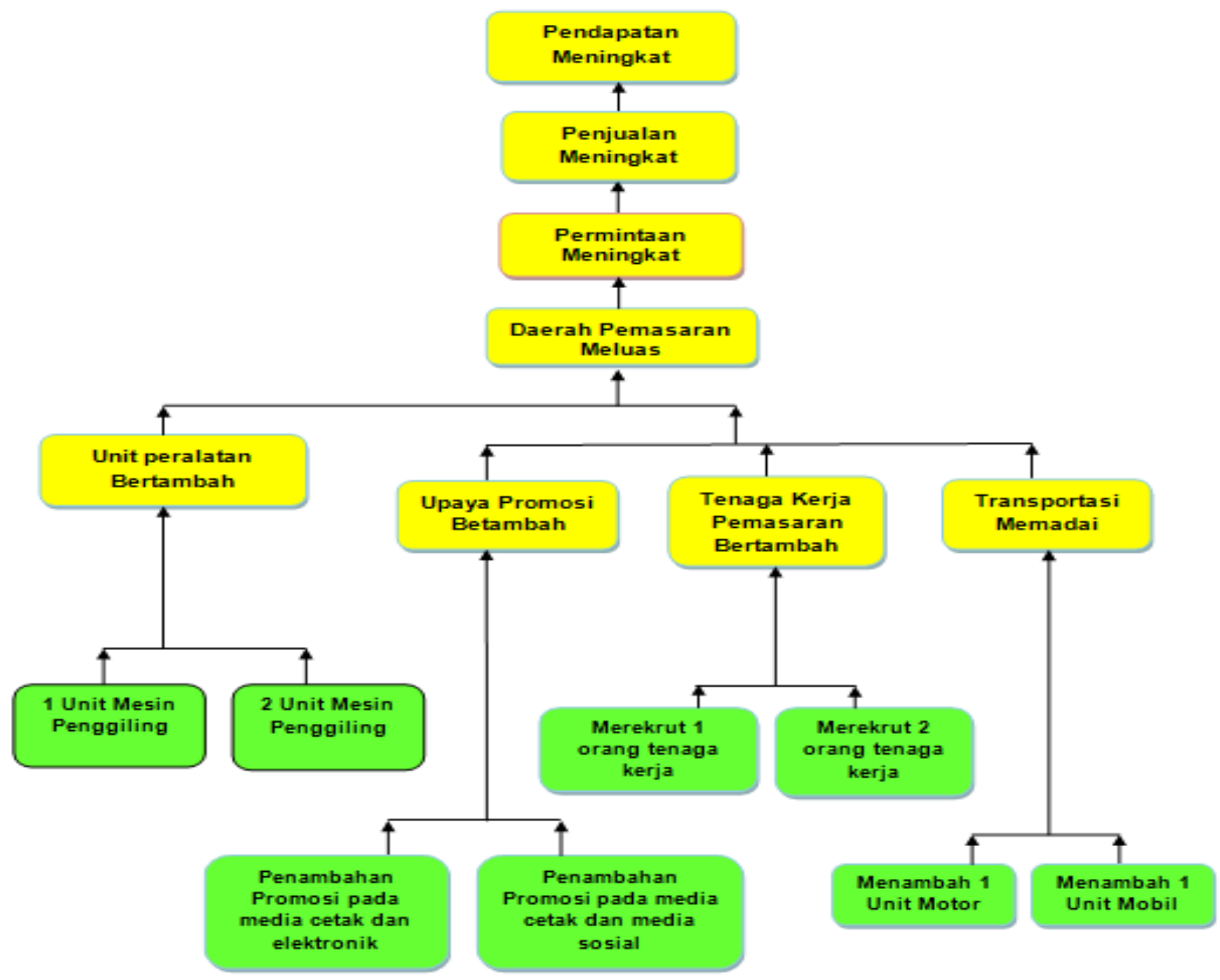


Berdasarkan gambar 3, diketahui bahwa sasaran utama yang ingin dapat dicapai dengan beberapa tindakan pada usaha " $X$ ". "Daerah Pemasaran Meluas" menjadi sasaran utama ini dapat dicapai dengan cara menambah upaya promosi pada media cetak dan elektronik atau media cetak dan sosial media, menambah sarana transportasi 1 unit motor atau 1 unit mobil, menambah tenaga kerja 2 orang atau 1 orang dan menambah 1 atau 2 unit mesin penggiling.

\section{Analisis Keputusan}

Analisis keputusan adalah pola berpikir sistematis dalam pengambilan keputusan, yang bertujuan untuk mengidentifikasi apa yang harus dilakukan, pengembangan kriteria khusus untuk mencapai tujuan, mengevaluasi alternatif tindakan yang tersedia yang berhubungan dengan kriteria dan mengidentifikasi kemungkinan resiko yang melekat pada suatu keputusan tersebut (Amran, 2011).

Ada beberapa langkah dalam melakukan analsis keputusan, yaitu sebagai berikut :

a. Pernyataan keputusan adalah memusatkan perhatian pada persoalan yang terpilih. Pernyataan keputusan tidak hanya menujukkan maksud dari suatu keputusan, tetapi juga tindakan yang bagaimana yang harus diambil agar keputusan tersebut dapat dijalankan.

b. Kriteria keputusan adalah kemampuan memberi gambaran suatu keadaan yang lebih jelas dan lebih terperinci mengenai hasil keputusan yang diambil. Kriteria keputusan juga dapat memperjelas ciri-ciri atau sifat-sifat dari keputusan tersebut.

c. Alternatif keputusan adalah terdiri atas beberapa alternatif tindakan/ keputusan yang akan diambil untuk mencapai sasaran yang telah ditetapkan. Alternatif ini disesuaikan dengan sasaran yang ingin dicapai.

d. Evaluasi alternatif terhadap kriteria keputusan adalah prosedur yang digunakan untuk mengetahui alternatif yang paling baik yang dapat memenuhi sasaran. Evaluasi alternatif ini dilakukan dengan langkah-langkah, yaitu : pertama, menetapkan nilai masing-masing alternatif keputusan (BA) yang telah ditetapkan menurut kriteria demi kriteria sehingga jumlah nilai semua alternatif keputusan menjadi 1,00. Kedua, memasukkan nilai alternatif keputusan yang telah ditetapkan ke aplikasi Analisis Hirarki Proses (AHP). Alternatif yang memiliki total nilai pembobotan tertinggi merupakan alternatif terpilih.

e. Alternatif terpilih adalah alternatif terbaik dari alternatif keputusan yang telah diseleksi pada evaluasi alternatif terhadap kriteria keputusan. Alternatif inilah yang akan menjadi tindakan untuk mencapai sasaran utama.

Berdasarkan alternatif tindakan yang telah diuraikan, maka alternaif tindakan tersebut dapat dianalisis dengan menggunakan langkah-langkah analisis keputusan untuk memperoleh alternatif keputusan yang terbaik. Adapun analisis keputusan untuk alternatif-alternatif tindakan tersebut sebagai berikut:

1. Analisis keputusan untuk tindakan "Menentukan Cara Memenuhi Jumlah Tenaga Kerja Pada Bagian Pemasaran".

a. Pernyataan keputusan yaitu menentukan cara memenuhi jumlah tenaga kerja yang dibutuhkan. 
b. Kriteria keputusan

$\mathrm{K}_{1}$ :Meningkatkan produktivitas

$\mathrm{K}_{2}$ : Biaya Terjangkau
Bobot

0,60

$\underline{0,40}$

1,00

Bobot tertinggi diberikan kepada K1yaitu sebesar 0,60 hal ini disebabkan usaha " $X$ " lebih mengutamakan meningkatkan produktivitas usaha guna memenuhi tenaga kerja pada bagian pemasaran agar dapat memasarkan produknya sesuai dengan target daerah pemasaran, K2 memiliki bobot sebesar 0,40 hal ini disebabkan usaha " $\mathrm{X}$ " mengutamakan biaya yang murah guna memenuhi jumlah tenaga kerja pada bagian pemasaran.

Alternatif keputusan :

$\mathrm{A}_{1}$ : Menentukan 1 orang tenaga kerja pemasaran

$\mathrm{A}_{2}$ : Menentukan2 orang tenaga kerja pemasaran

c. Evaluasi Alternatif

AHP digunakan untuk menentukan alternatif tindakan dengan kriteria biaya dan produktivitas diatas. Hasil analisis menunjukkan bahwa alternatif tindakan yang paling diprioritaskan dalam menentukan tenaga kerja pada bagian pemasaran yaitu dengan menambah 1 orang tenaga kerja dengan nilai sebesar 0,568 sedangkan alternatif tindakan yang kedua menambah 2 orang tenaga kerja pemasaran dengan nilai sebesar 0,432.

d. Alternatif Terpilih

Berdasarkan evaluasi altrenatif terhadap kriteria di atas, maka terlihat bahwa alternatif tindakan yang memiliki total nilai tertinggi sebesar 0,568 ini menunjukkan bahwa alternatif yang terpilih adalah "Menentukan1 orang tenaga kerja pada bagian pemasaran".

\section{Gambar 4}

Evaluasi Alternatif Tindakan "MenentukanCara Memenuhi Jumlah Tenaga Kerja pada Bagian Pemasaran" Usaha Pada "X", di Kelurahan Majelling, Kecamatan Maritengngae, Kabupaten Sidrap, 2017.

1 oranq tenaqa keria pemasaran .568

2 oranq tenaqa keria pemasaran .432

Sumber : Data Primer Setelah Diolah, 2017.

2. Analisis keputusan untuk tindakan "Menentukanmedia promosi".

a. Pernyataan keputusan yaitu menentukan cara menambah media promosi

b. Kriteria keputusan Bobot

$\mathrm{K}_{1}$ :Waktu pelaksanaan efesien

0,10

$\mathrm{K}_{2}$ : Biaya Murah

0,40

$\mathrm{K}_{3}$ :Usaha lebih dikenal

$\underline{0,50}$

1,00 
Bobot tertinggi diberikan kepada K3 yaitu sebesar 0,50 hal ini disebabkan usaha " $X$ " lebih mengutamakan menambah media promosi diharapkan usaha lebih diketahui keberadaannya oleh masyarakat, karena makin banyak kegiatan promosi akan mempengaruhi tingkat minat para konsumen yang mengetahui keberadaan usaha maupun produk, K2 memiliki bobot sebesar 0,40 hal ini disebabkan usaha " $X$ " mengutamakan biaya yang murah untuk melakukan promosi pada perusahaan, dan K3 memiliki bobot yakni 0,10 hal ini disebabkan perusahaan tidak terlalu menekankan waktu pelaksanaan yang efesien untuk melakukan promosi.

Alternatif keputusan :

$\mathrm{A}_{1}$ : Menentukan promosi pada media cetak dan media elektronik

$\mathrm{A}_{2}$ : Menentukan promosi pada media sosial dan media cetak

c. Evaluasi Alternatif

Gambar 5

Evaluasi Alternatif TindakanUsaha "Menentukan Media Promosi" Pada "X", di Kelurahan Majelling, Kecamatan Maritengngae, Kabupaten Sidrap, 2017.

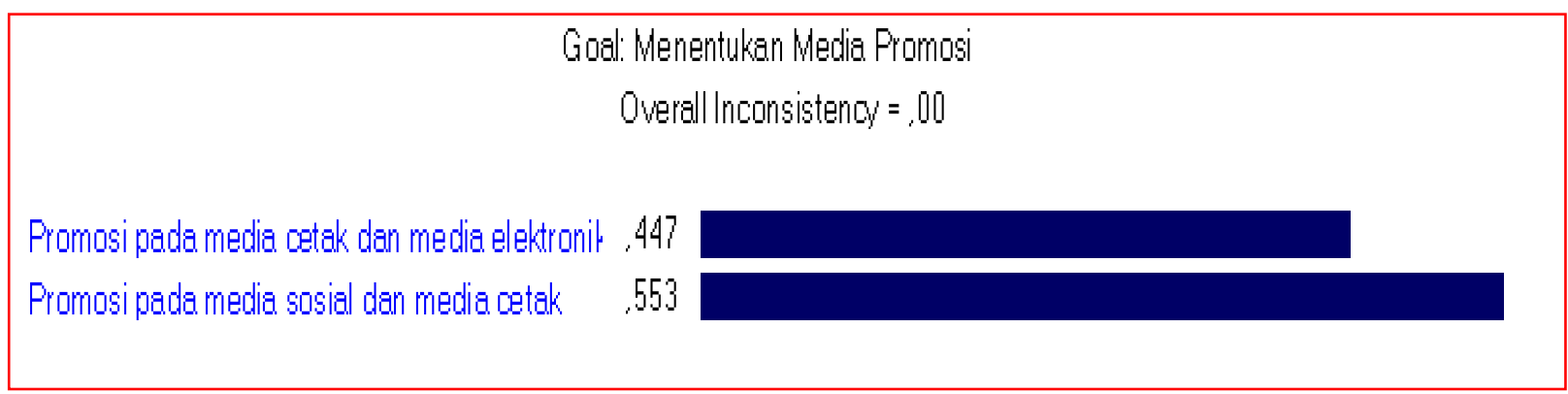

Sumber : Data Primer Setelah Diolah, 2017.

Berdasarkan gambar 5, hasil olah data AHP digunakan untuk menentukan evaluasi alternatif terhadap kriteria di atas, terlihat bahwa alternatif tindakan yang paling diprioritaskan dalam menentukan media promosi yaitu dengan menentukan promosi pada media sosial dan media cetak dengan nilai sebesar 0,553 sedangkan alternatif tindakan yang kedua menentukan promosi pada media cetak dan media elektronik dengan nilai sebesar 0,447.

d. Alternatif Terpilih

Berdasarkan evaluasi altrenatif terhadap kriteria di atas, maka terlihat bahwa alternatif tindakan yang memiliki total nilai tertinggi sebesar 0,553 sehingga alternatif keputusan yang terpilih adalah "menentukan media promosi melaui media sosial dan media cetak".

3. Analisis keputusan untuk tindakan "Alat transportasi memadai".

a. Pernyataan keputusan yaitu menentukan alat transportasi yang akan ditambah.

b. Kriteria keputusan

Bobot

$\mathrm{K}_{1}$ : Mudah dalam memasarkan

0,30

$\mathrm{K}_{2}$ : Waktu yang efesien

0,20

$\mathrm{K}_{3}$ :Biaya Murah 
Pada penentuan kriteria keputusan, K1 memiliki bobot yakni 0,30, K2 memiliki bobot sebesar 0,20 dan K3 0,50. Hal ini disebabkan karena dengan adanya alat transportasi yang memadai memudahkan usaha " $X$ " dalam memasarkan produk dengan biaya yang murah serta waktu lebih efesien dengan adanya alat transportasi yang memadai.

c. Alternatif keputusan :

$\mathrm{A}_{1}$ : memilih 1 unit mobil

$\mathrm{A}_{2}$ : memilih 1 unit motor

d. Evaluasi Alternatif

Gambar 6

Evaluasi Alternatif Tindakan Usaha "Memilih Alat transportasi" Pada" $X$ ", di

Kelurahan Majelling, Kecamatan Maritengngae, Kabupaten Sidrap, 2017.

Sumber : Data Primer Setelah Diolah, 2017.

Berdasarkan gambar 6, hasil olah data AHP digunakan untuk menentukan evaluasi alternatif terhadap kriteria di atas, terlihat bahwa alternatif tindakan yang paling diprioritaskan dalam memilih alat transportasi yaitu dengan memilih 1 unit mobil, dengan nilai sebesar 0,615 sedangkan alternatif tindakan yang kedua memilih 1 unit motor dengan nilai sebesar 0,385.

e. Alternatif Terpilih

Berdasarkan evaluasi altrenatif terhadap kriteria di atas, maka terlihat bahwa alternatif tindakan yang memiliki total nilai tertinggi sebesar 0,615 sehingga alternatif keputusan yang terpilih adalah "Memilih 1 unit motor"

4. Analisis untuk keputusan untuk tindakan "menambah peralatan mesin penggilingan".

a. Pernyataan keputusan yaitu menentukan ukuran mesin penggilingan

b. Kriteria keputusan

Bobot

$\mathrm{K}_{1}$ : Dapat memproduksi sesuai kebutuhan

0,20

$\mathrm{K}_{2}$ : Biaya murah

0,30

$\mathrm{K}_{3}:$ Memudahkan dalam proses produksi

$\underline{0,50}$

1,00

Pada penentuan kriteria keputusan, K3 memiliki bobot yakni 0,50. Hal ini disebabkan karena perusahaan lebih mengutamakan memudahkan dalam proses produksi dengan adanya mesin penggiling diharapkan dapat lebih memudahkan perusahaan. K2 memiliki bobot tertinggi kedua yaitu 0,30. Hal ini disebabkan karena perusahaan kasus tidak mengutamakan biaya yang murah dalam menambah 
peralatan yang dibutuhkan perusahaan. Sedangkan K3 memiliki bobot terendah yakni 0,20. Hal ini disebabkan perusahaan kasus tidak menekankan memproduksi sesuai kebutuhan.

c. Alternatif keputusan :

$\mathrm{A}_{1}$ : menambah 1 unit mesin penggiling besar

$\mathrm{A}_{2}$ : menambah1 unit mesin penggiling kecil

d. Evaluasi Alternatif

Gambar 7

Evaluasi Alternatif Tindakan Usaha "Menambah PeralatanMesin

Penggiling" Pada" $X$ ", di Kelurahan Majelling,KecamatanMaritengngae,Kabupaten

Sidrap, 2017.

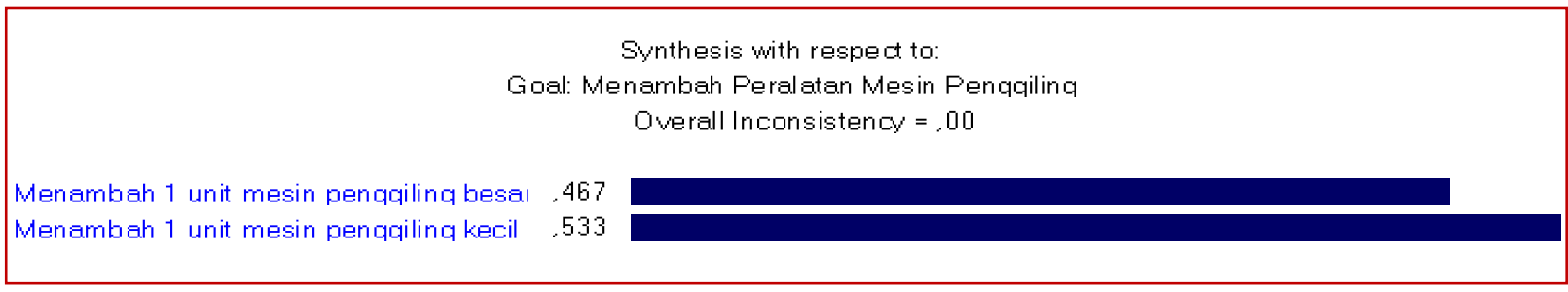

Sumber : Data Primer Setelah Diolah, 2017.

Berdasarkan gambar 7, hasil olah data AHP digunakan untuk menentukan evaluasi alternatif terhadap kriteria di atas, terlihat bahwa alternatif tindakan yang paling diprioritaskan dalam menambah mesin penggiling yaitu dengan menambah 1 unit mesin penggiling kecil, dengan nilai sebesar 0,533 sedangkan alternatif tindakan yang kedua menambah 1 unit mesin penggiling besar dengan nilai sebesar 0,467 .

e. Alternatif Terpilih

Berdasarkan evaluasi altrenatif terhadap kriteria di atas, maka terlihat bahwa $\mathrm{A}_{2}$ memiliki total nilai tertinggi yaitu 0,533. Hal ini menunjukkan bahwa alternatif yang terpilih adalah "menambah1 unit mesin penggiling".

\section{Tindakan Terpilih}

Hasil analisis keputusan dari beberapa alternatif tindakan, telah terpilih satu keputusan tindakan yang terbaik yaitu dengan nilai yang tertinggi dibandingkan dengan alternatif lainnya pada masing-masing persoalan agrosistem. Keputusan tindakan terpilih ini diharapkan dapat membantu perusahaan dalam pengembangan usaha. Alternatif tindakan terpilih tersebut antara lain :

1. Menentukan1 orang tenaga kerja

2. Menentukanmedia promosi berupa media sosial dan media cetak

3. Memilih 1 unit transportasi berupamotor

4. Menambah 1 unit mesin penggiling kecil. 


\section{Gambar 8}

Pohon Tindakan Terpilih Pada Usaha "X", di Kelurahan Majelling, Kacamatan Maritengngae, Kabupaten Sidrap, 2017.

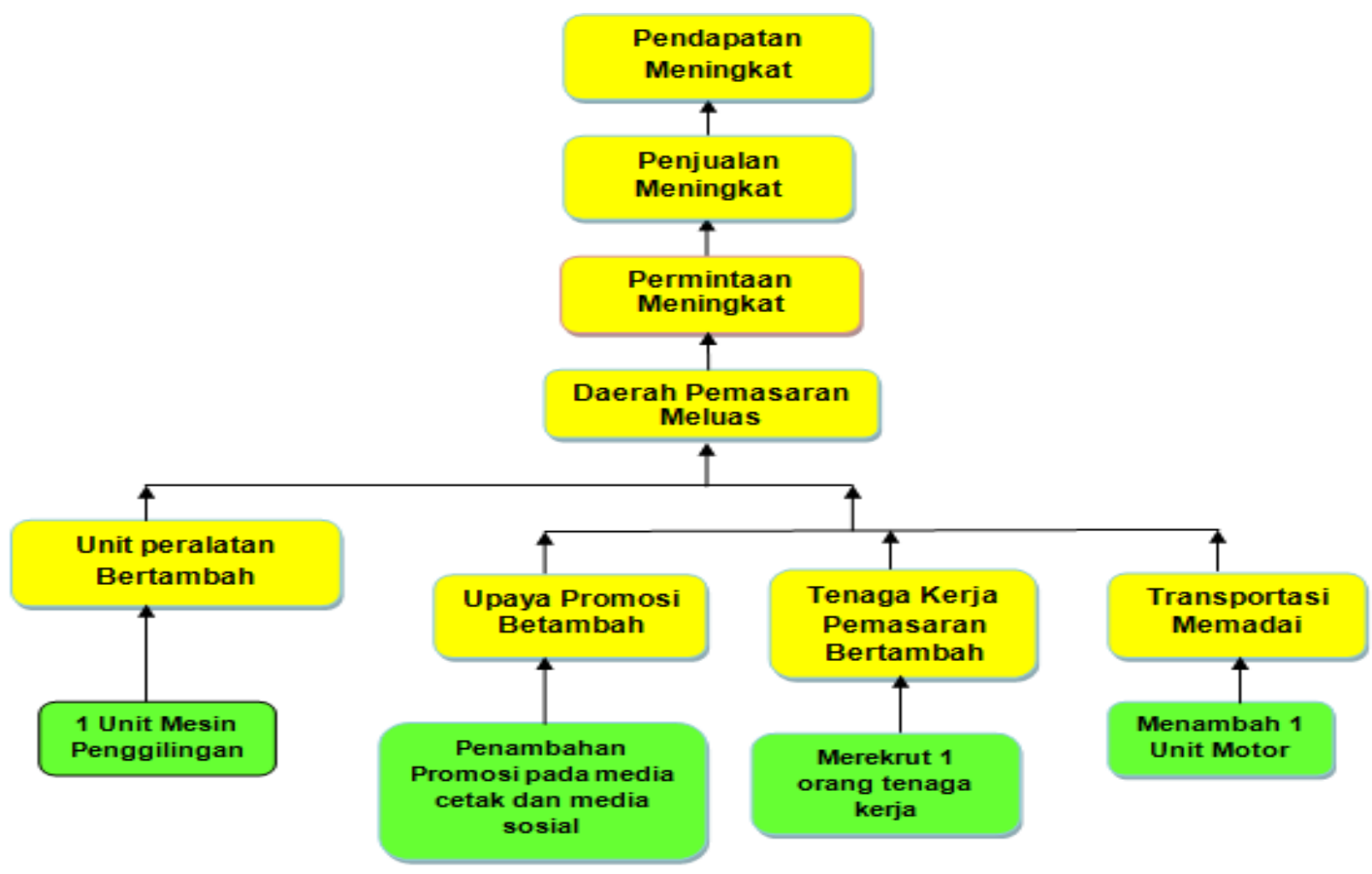

Berdasarkan gambar 8, diketahui bahwa sasaran utama yang ingin dapat dicapai dengan beberapa tindakan pada usaha " $X$ ". "Daerah Pemasaran Meluas" menjadi sasaran utama ini dapat dicapai dengan cara menambah tenaga kerja 1 orang, menambahmedia promosi melalui media sosial dan media cetak, memilih 1 unit motor dan menambah 1 unit mesin penggilingan.

\section{Kesimpulan}

Mengetahui alur agrosistem kasus sangat diperlukan untuk menemukan masalah yang sebenarnya dihadapi oleh agrosistem kasus tersebut. Sama halnya dengan usaha " $X$ ", penemuan masalah yang dihadapi dapat ditemukan dalam waktu kurang lebih 1 bulan. Penetapan masalah ini tentunya didapatkan setelah memahami kondisi sumber daya dan kinerja yang dimiliki " $X$ ".

Merumuskan masalah yang dihadapi oleh agrosistem kasus maka tahapan selanjutnya adalah merumuskan sasaran yang ingin dicapai. Perumusan atau penetapan sasaran ini harus terukur agar memudahkan dalam menentukan tindakan yang akan dilaksanakan. Pada agrosistem kasus, perumusan sasaran hingga mendapatkan tindakan yang tepat memerlukan waktu selama kurang lebih 3 minggu. Tindakan yang telah dirumuskan seperti menambah jumlah tenaga kerja, menambah mesin penggilingan, menambah alat transportasi dan menambah media promosi, setelah dilakukan analisis keputusan akan dijadwalkan pelaksanaannya. Penjadwalan pelaksanaan tindakan ini perlu dilakukan secara matang yaitu dengan 
mempertimbangkan unsur kepentingan dari setiap tindakan. Hal ini dilakukan dalam rangka perwujudan visi sebuah usaha.

\section{Daftar Pustaka}

Amran, 2011. Analisis Alternatif Tindakan Pengembangan Agrosistem. Diakses melalui http://sayangpetani.wordpress.com. Pada tanggal 29 Oktober 2017. Pada pukul 19.56 WITA. Makassar.

Djamaluddin. 2010. Problematisasi Perusahaan. http://eprints.ums.ac.id. Diakses pada tanggal 17 Mei 2017, pukul 21.24 WITA. Makassar.

Hasab, Ap. 2010. Sasaran Perusahaan. http://eprints.ums.ac.id. Diakses pada tanggal 18 Mei 2017, pukul 22.21 WITA. Makassar.

Mantra,Dodi. 2011. Pengajarpada Program Studi Ilmu Hubungan Internasional, FISIP, Universitas Al Azhar Indonesia. Paper dalam Konvensi Nasional Asosiasi Ilmu Hubungan Internasional Indonesia (AIHI) Bandung

Sartono. 2011. Masalah-Masalah Agrosistem. Jakarta: PT Kompas Media Nussantara.

Sumarto. 2009. Meningkatkan Komitmen Dan Kepuasan Untuk Menyurutkan Niat. Jakarta: PT. Gramedia Pustakan Utama.

Wirakartakusumah, M. A. 1997. Telaah Perkembangan industri Pangan Di Indonesia. Jurnal Pangan. Vol. VIII No. 1. Penerbit Bulog. Jakarta 